\title{
Agencies of Coercion: Armies and Internal Security Forces YEZID SAYIGH
}

Department of War Studies, King's College London, London, U.K.; e-mail:

yezid.sayigh@kcl.ac.uk

doi:10.1017/S0020743811000572

The readiness of army commanders in Egypt and Tunisia to counter the internal security agencies deployed by their own governments against civilian protestors in early 2011 proved decisive in bringing down presidents-for-life Husni Mubarak and Zayn al-'Abidin bin 'Ali. This brings into sharp relief questions about how to approach and assess the various coercive agencies of the state. Should we regard them as different branches of a single coercive apparatus, through which the state seeks to exercise a monopoly on the legitimate means of violence? Or should we see them as manifestations of more fragmented political institutions and social forces and consequently as performing distinct, and potentially divergent, functions in constantly evolving relation to each other?

In Egypt on the eve of Mubarak's departure, the Ministry of Interior had 1.4 million employees, encompassing the police, armed security forces border guards, and an army of informers; in Bin 'Ali's Tunisia, internal security personnel numbered some 120,000; and in Yemen, the Political Security Organization answering directly to President Ali Abdullah Saleh has an estimated strength of 150,000. The Saudi Ministry of Interior is believed to have 500,000 police officers, security agents, and informers on its payroll, while the reconstructed Iraqi Security Forces include from 415,000 to 600,000 internal security personnel of all types.

In many Western countries or countries that had already attained independence by the 20th century, historical struggles between different political and social actors shaped the precise nature and powers of police forces and determined whether authority over them was to be federal or regional; the outcomes reflected relations and balances between regions, urban and rural elites, or socioeconomic classes. ${ }^{1}$ But in the Middle East and North Africa, as in other parts of the colonized world, most police forces emerged from colonial militaries or, continuing the pattern under postindependence governments, were hived off national armies. This explains the military character of a great many police forces: their basic training, system of ranks, and organization are broadly similar to those of a military. Just as important, there is a shared militaristic culture between the police and the armed forces that emphasizes the routine use of violence and masculine values. ${ }^{2}$ The establishment of intelligence agencies has followed much the same trend, again being born, in Dionysian fashion, from the thigh of national armed forces in the independence era. Coup-proofing by governments from the 1970s onward resulted in a proliferation of additional intelligence agencies entrusted with monitoring one another. Whether attached to the military or under the direct control of ruling parties, presidential offices, or royal courts, almost all engage in policing their own populations. And all are tasked with regime security, even when in implicit or open competition with each other.

Regime protection has also prompted the formation of paramilitary internal security agencies fielding heavy weaponry: sarāy $\bar{a}$ al-difa $\bar{a}^{c}$ (defense companies) and sarāya alsira $\bar{a}^{c}$ (struggle companies) in the Syria of Hafiz al-Asad, the Central Security Forces 
in Yemen, and Libya's Qadhafi-era Revolutionary Guards Corps, in addition to partyled forces such as the Popular Army and Fedayeen Saddam in pre-2003 Iraq. This is primarily a feature of the region's republics, although the Saudi National Guard arguably performs much the same function and is similarly armed. The militarization of internal security has become even more pronounced since 9/11. Throughout the Middle East, new police units have been created or existing ones retooled to perform a counterterrorism function. The forms vary but whether SWAT teams, commando-type special forces, or dedicated counterterrorism battalions, all are militarized in their armament and training. Most countries in the region already had paramilitary gendarmeries: 60,000 in Algeria, 50,000 in Morocco, and 150,000 in Turkey, to mention just a few. Reflecting the trend, Jordan created a wholly new General Directorate of Gendarmerie in 2008, and even the nonstate Palestinian Authority and Kurdish Regional Government have transformed former guerilla forces into armed constabulary units with U.S. training.

If this survey reveals anything, then, it is the hybrid nature and purposes of the coercive apparatuses of many Middle Eastern states. Few, if any, operate in clearly demarcated spheres of military versus internal security. This is further underlined by the internal security role constitutionally assigned to national armies around the region. ${ }^{3}$ Yet even though few of these armies face any real prospect of waging conventional, interstate war, they are generally reluctant to engage in law and order missions, not least because of the potential strain on the loyalty and cohesion of their rank and file. Indeed, in the 1990s this concern prompted the Algerian and Turkish militaries to subcontract considerable responsibility for counterinsurgency to state-sponsored village guards.

The behavior of the Egyptian and Tunisian armies in early 2011 revealed distaste for the excesses of their countries' internal security agencies. There are echoes here of Brazil's abertura of the 1970s, in which the army's desire to curb the confusion of roles and the autonomy of militarized security and intelligence agencies was a critical factor enabling democratization. ${ }^{4}$ The "Arab Spring" may reveal more such fissures and may lead to additional cases in which military commanders are willing to endorse a controlled transition to a more liberal politics; for various reasons, the initiative in these cases will not come from internal security forces or associated paramilitary agencies.

Yet it is wise not to overstate the parallels. The era of military-backed presidents for life may be drawing to a close, and that of absolute monarchs is now under pressure, but the extensive proliferation, militarization, and hybrid nature of the agencies of coercion emanate from state-building processes that remain unfinished and societal cleavages that remain unresolved in much of the Middle East. The struggle to create free markets of politics, especially where the development of free markets of economics has been distorted or marked by cronyism, will trigger multiple realignments with, and within, the coercive apparatus, in some cases generating a free market of the means of violence.

\section{NOTES}

\footnotetext{
${ }^{1}$ See Diane E. Davis and Anthony W. Pereira, eds., Irregular Armed Forces and Their Role in Politics and State Formation (Cambridge: Cambridge University Press, 2003).

${ }^{2}$ Definitions of militarism vary according to author and context. A minimalist but useful one sees it as "a certain cult of brute force." Boubacar N'Diaye, “To 'Midwife'—and Abort—a Democracy: Mauritania's Transition from Military Rule, 2005-2008," Journal of Modern African Studies 47 (2009): 144. A more classic definition refers to it as "a set of attitudes and social practices which regards war and the preparation for war as
} 
a normal and desirable social activity." Michael Mann, "The Roots and Contradictions of Modern Militarism," New Left Review 1, no. 162 (1987): 35.

${ }^{3}$ These patterns are generally also true in Latin America. Charles Call, "War Transitions and the New Civilian Security in Latin America," Comparative Politics 35 (2002): 1-20.

${ }^{4}$ See, for example, Alfred Stepan, Rethinking Military Politics: Brazil and the Southern Cone (Princeton, N.J.: Princeton University Press, 1988). 